Herschel at the Cape DIARIES AND CORRESPONDENCE of Sir John Herschel, 1834-1838 
THIS PAGE INTENTIONALLY LEFT BLANK 
NUMBER ONE

History of Science Series

HUMANITIES RESEARCH CENTER

THE UNIVERSITY OF TEXAS 


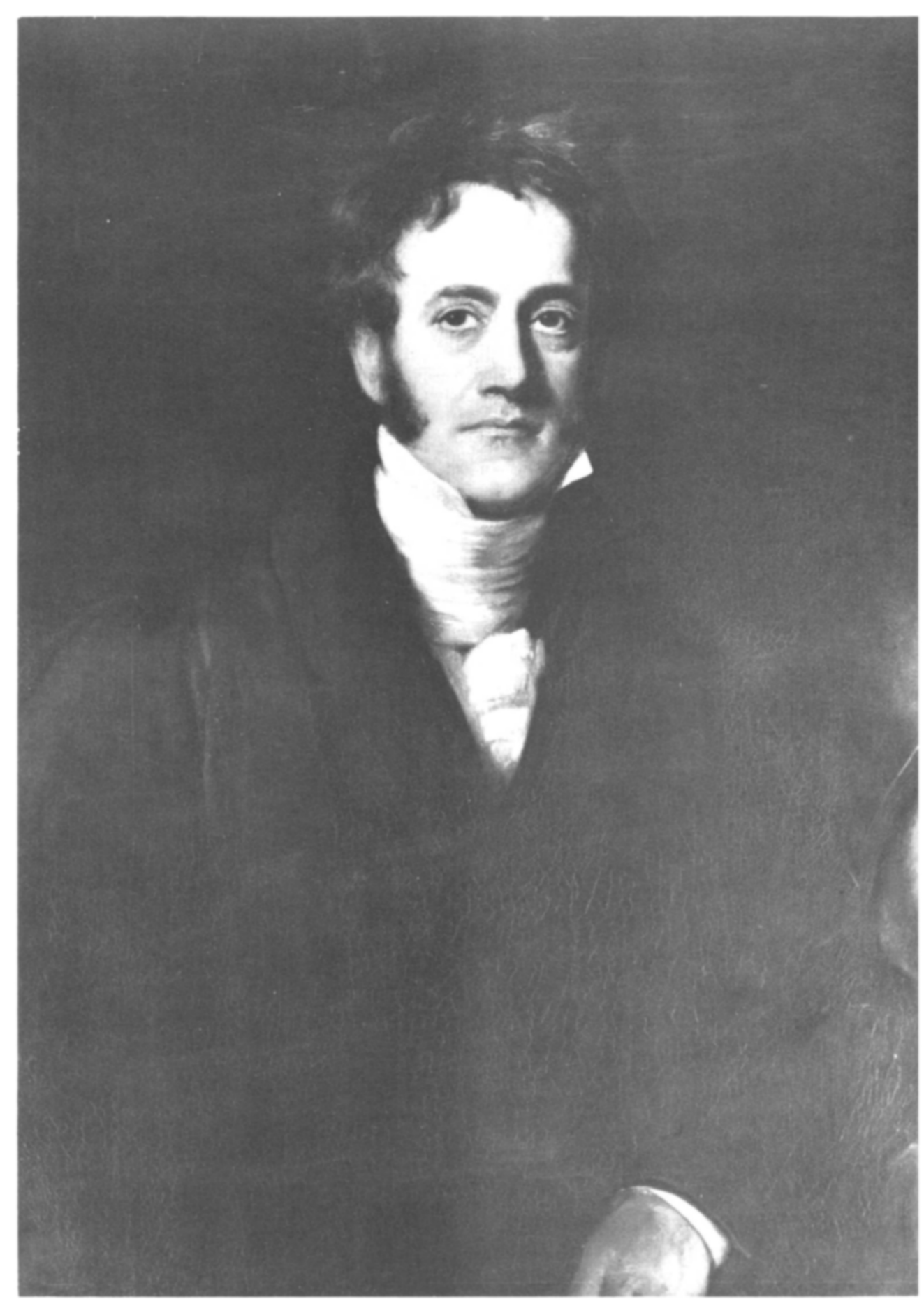

The "admirable likeness," Pickersgill's portrait of Sir John Herschel. (By permission of the Master and Fellows of St. John's College, Cambridge) 

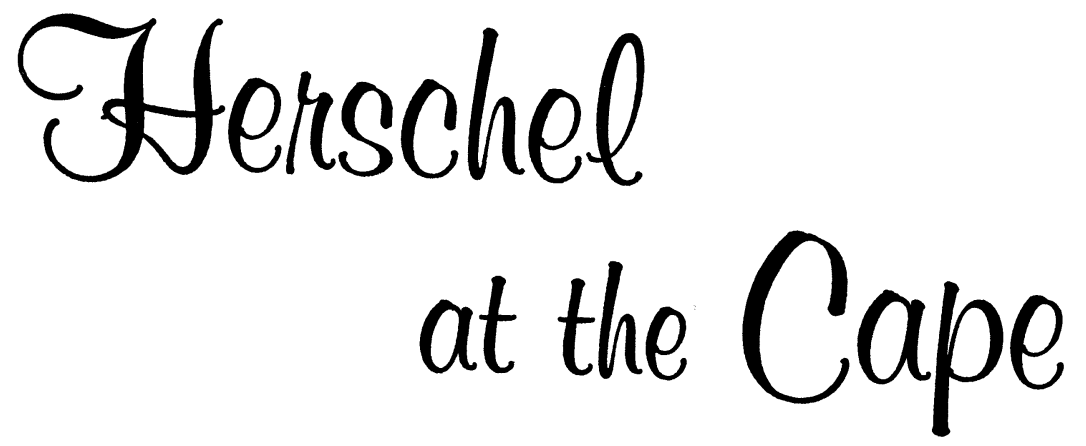

DIARIES AND CORRESPONDENCE OF Sir John HERSChEL, 1834-1838

EDITED WITH AN INTRODUCTION BY

David S. Evans, Terence J. Deeming, Betty Hall Evans, Stephen Goldfarb

UNIVERSITY OFTEXAS PRESS AUSTIN 
Copyright (C) I 969 by the University of Texas Press First paperback printing 2014

All rights reserved

Printed in the United States of America

Requests for permission to reproduce material from this work should be sent to:

Permissions

University of Texas Press

P.O. Box 7819

Austin, TX 78713-7819

http://utpress.utexas.edu/index.php/rp-form

Library of Congress Catalog Number 69-630I3

ISBN 978-0-292-72008-4, paperback

ISBN 978-0-292-72022-o, library e-book

ISBN 978-0-292-72054-I, individual e-book 


\section{To Our Parents}


THIS PAGE INTENTIONALLY LEFT BLANK 


\section{F O R E W O R D}

With the publication of Herschel at the Cape, the Humanities Research Center in The University of Texas initiates a series on the history of science.

The proposed publications will range over a wide variety of subjects. Each should be significant in itself. The significance of sponsorship by the Humanities Research Center is manifest: This series bears evidence to the fact that the history of science provides essential threads in the broader history of man's experience.

Harry Ransom 
THIS PAGE INTENTIONALLY LEFT BLANK 